\title{
ANTICHOLINESTERASE ACTIVITY OF ENDEMIC PLANT EXTRACTS FROM SOQOTRA
}

\author{
Hussein Bakthir ${ }^{\mathrm{a}}$, Nasser A. Awadh Ali*b, Norbert Arnold ${ }^{\mathrm{c}}$, Axel Teichert ${ }^{\mathrm{c}}$, and Ludger \\ Wessjohann ${ }^{\mathrm{c}}$
}

${ }^{a}$ Department of Pharmacology and Pharmaceutics, Faculty of Pharmacy, University of Aden, Aden, Yemen, ${ }^{b}$ Department of Pharmacognosy, Faculty of Pharmacy, Sana'a University, P.O. Box 13150, Yemen. 'Leibniz Institute of Plant Biochemistry, Department of Bioorganic Chemistry, Weinberg 3, 06120 Halle/Saale, Germany

*E-mail: alinasser9678@yahoo.com

\begin{abstract}
:
A total of 30 chloroform and methanol extracts from the following endemic Soqotran plants Acridocarpus socotranus Olive, Boswellia socotranao Balf.fil, Boswellia elongata Balf. fil., Caralluma socotrana N. Br, Cephalocroton socotranus Balf.f, Croton socotranus Balf. fil.., Dendrosicycos socotrana Balf.f., Dorstenia gigas Schweinf. ex Balf. fil., Eureiandra balfourii Cogn. \& Balf. fil., Kalanchoe farinaceae Balf.f, Limonium sokotranum (Vierh) Radcl. Sm), Oldenlandia pulvinata, Pulicaria diversifolia( Balf. and Pulicaria stephanocarpa Balf. were screened for their acetylcholinesterase inhibitory activity by using in vitro Ellman method at 50 and $200 \mu \mathrm{g} / \mathrm{ml}$ concentrations. Chloroform extracts of Croton socotranus, Boswellia socotrana, Dorstenia gigas, and Pulicaria stephanocarpa as well as methanol extracts of Eureiandra balfourii exhibited inhibitory activities higher than $50 \%$ at concentration of $200 \mu \mathrm{g}$. At a concentrations of $50 \mu \mathrm{g}$, the chloroform extract of Croton socotranus exhibited an inhibition of $40.6 \%$.
\end{abstract}

Key words: plant extracts, acetylcholinesterase inhibitors, Soqotra, Alzheimer's disease

\section{Introduction}

Alzheimer's disease (AD) is a progressive neurological disorder leading to impairment of memory and behavioral disturbances. Epidemiological data indicate that up to 4 million people are affected in the USA. AD is accompanied with cholinergic deficit in the brain, resulting in decrease in acetylcholine level (Zarotsky et al 2003). The inhibition of the acetylcholinesterase, which is responsible for the hydrolysis of acetylcholine, represents the most effective approach for finding of new anti $\mathrm{AD}$ compounds from natural sources. Tacrine, donepezil, rivastigmine and galanthamine with $\mathrm{AChE}$ inhibitory activity are used for treating mild type of $\mathrm{AD}$ but they possess some side effects which limits their use (Zarotsky, et al 2003, Melanie-Jayne et al 2003, Schneider, 2001).

Plants still continue to be almost the exclusive source of drugs which have been shown to contain potential new AChE inhibitors. A number of reports concerning the anticholinesterase screening of plant extracts has been published in the literature (Howes et al 2003, Melanie-Jayne et al 2003, Houghton, et al 2006) Extracts from the endemic flora of Soqotra Island, which is a home to 404 endemic plants of about 850 plants (Miller, and Morris, 2004) may represent a valuable source of new secondary metabolites with high diverse biological activities, in particular for finding new natural AChE inhibitors.

In this paper, we studied thirty extracts prepared from different parts of fourteen endemic Soqotran plants for their AChE -inhibitory activity using Ellman's colorimetric method in 96-welled microplate.

\section{Materials and Methods Plant materials}

The plant materials were collected in March 2006 from different locations on Soqotra Island (Table 1). The plants were taxonomically identified at Soqotra Archipelago Conservation and Development Program (SCDP), Yemen. Species names are according to International Plant Name Index (IPNI) (http://www.ipni.org). Voucher specimens of the plant material were deposited at the Pharmacognosy Department, Aden University, Yemen.

\section{Preparation of extracts}

Air-dried and powdered plant materials ( $10 \mathrm{~g})$ were extracted under shaking at room temperature successively with $\mathrm{CHCl}_{3}(4 \times 100 \mathrm{ml})$, followed by $\mathrm{MeOH}(4 \times 100 \mathrm{ml})$. The obtained extracts were filtered, and evaporated to dryness in vacuo at $40{ }^{\circ} \mathrm{C}$. The resulting crude extracts were stored at $4{ }^{\circ} \mathrm{C}$. 


\section{Chemicals}

Acetylthiocholine iodide (ATCI), 5,5' -dithiobis-(2-nitrobenzoic acid) (DTNB), galanthamin, bovine serum albumine (BSA) and acetylcholinesterase from horse serum (lyophilized, $500 \mathrm{U} /$ vial solid, $65 \mathrm{U} / \mathrm{mg}$ ) were purchased from Sigma (Germany). The following buffers were used: Buffer A: $50 \mathrm{mM}$ Tris-HCl, $\mathrm{pH} \mathrm{8,} \mathrm{containing} \mathrm{0.1 \%} \mathrm{BSA;} \mathrm{Buffer} \mathrm{B:} 50$ $\mathrm{mM}$ Tris- $\mathrm{HCl}$, $\mathrm{pH} 8$ containing $0.1 \mathrm{M} \mathrm{NaCl}, 0.02 \mathrm{M} \mathrm{MgCl}_{2} \times 6 \mathrm{H}_{2} \mathrm{O}$

\section{Microplate assay for AChE inhibitory activity}

AChE inhibitory activity was detected by a microtitre plate assay based on Ellman's method (Ellman et al 1961, Rhee, et al 2001), using acetylthiocholine as a substrate. In 96-well plates, $25 \mu 1$ of $15 \mathrm{mM}$ ATCI, (43 mg/ $10 \mathrm{~mL}$ Millipore water), $125 \mu \mathrm{l}$ of $3 \mathrm{mM}$ DTNB, $(11.9 \mathrm{mg} / 10 \mathrm{~mL}$ buffer B), $50 \mu \mathrm{l}$ of buffer A and $25 \mu 1$ of plant extract at concentration of 2 , and $0.5 \mathrm{mg} / \mathrm{ml}$ (final concentration in the assay: $0.2,0.05 \mathrm{mg} / \mathrm{ml}$ DMSO) were added and the absorbance was measured at $405 \mathrm{~nm}$ every $13 \mathrm{~s}$ for five times. After adding $25 \mu \mathrm{l}$ of $0.22 \mathrm{U} / \mathrm{ml}$ enzyme, $(0.34 \mathrm{mg}$ AChE dissolved in $100 \mathrm{~mL}$ buffer A), the absorbance was read again every $13 \mathrm{~s}$ for five times. The absorbance was measured using a Tecan GeniosPro micro plate reader (Tecan Group Ltd, Switzerland). Percentage of inhibition was calculated by comparing the rates for the sample to the blank (DMSO), control contained all components except the tested extract, galanthamine was used as positive control. The mean of four measurements for each concentration was determined $(n=4)$.

\section{Results and Discussion}

Fourteen endemic plant species belonging to eleven plant families were collected from Soqotra island in Yemen and a total of thirty extracts were screened for AChE inhibitory activity using Ellman's colorimetric method in 96-welled microplate, Table 1 gives the names of the plants investigated, their voucher specimen no, their families, and their traditional uses. The results obtained in two concentrations of all plant extracts are shown in Table 2.

At the concentration of $200 \mu \mathrm{g} / \mathrm{ml}$, the chloroform extracts from the bark of Croton socotranus, resin of Boswellia socotranus, leaves of Dorstenia gigas, leaves of Pulicaria stephanocarpa exhibited AChE inhibitory activity with more than $50 \%$ (with percent inhibition of $79.23,71.2,65.1$, and 61.4 , respectively). The methanol extract from tuber of Eureiandera balfouri showed at the same concentration an AChE inhibitory activity of $58.61 \%$. The rest of the extracts showed an AChE inhibitory activity below $50 \%$. Galanthamine was used as standard AChE inhibitor (positive control). At the concentration of $8 \mu \mathrm{g} / \mathrm{ml}$ galanthamine exhibited an AChE inhibitory activity of $87.43 \%$. At the concentration of 200 $\mu \mathrm{g} / \mathrm{ml}$, which was the concentration of the test extracts in this study, galanthamine showed complete inhibition of the enzyme activity.

In this study it was found that the AChE inhibitory activity (71.2\%) of resin of B. socotrana was more than the inhibitory activity $(46.34 \%)$ of the resin from B. elongata.. An inhibitory activity has been reported for 11-hydroxy -betaboswellic acid isolated from resins of Boswellia carterii. (Ota, and Houghton, 2005). The occurrence of boswellic acids is well documented in resins of the genus Boswellia, and the quantitative concentrations of the active 11-hydroxy -betaboswellic acid in the species of the genus can be different, which might explain the observed difference in AChE inhibitory activity between B. socotrana and B. elongata.

Currently no AChE inhibitory activity has been reported from the leaves of $D$. gigas. Phytochemical investigations of D. gigas leaves revealed the occurrence of furanocoumarins (Franke, et al 2001), a group of compounds reported to have AChE inhibitory activity (Kang, et al 2001, Miyazawa, et al 2004). The chloroform extract from P. stephanocarpa leaves showed moderate AChE inhibitory activity $\mathbf{( 6 1 . 4 3} \%$ enzyme inhibition) more than the methanolic extract. $(23.21 \%$ Enzyme inhibition). This higher AChE inhibitory activity can be explained by the higher content of essential oil with monoterpenoids, a group of compounds (e.g 1, 8-cineole, $\alpha$ - pinene,) reported to have AChE inhibitory activity (Houghton, et al 2006).

Croton socotranus species exhibited the highest AChE inhibitory activity in our study. According to databases, the Genus Croton comprises about 3100 epithets, under which only a few were investigated such as Croton hemiargyreus which contained alkaloids of berberine type that possessed AChE-inhibitory activity (Amaral, and Barnes, 1998). Further studies are necessary for the isolation and characterization of the active compound(s) from the active extract of C. socotranus.

\section{Acknowledgements}

The authors would like to thank Deutscher Akademischer Austauschdienst (DAAD) for a grant enabling the stay of Dr. Nasser A. Awadh Ali at the Leibniz Institute of Plant Biochemistry. We are also indebted to Soqotra Archipelago Conservation and Development Program (SCDP) for facilitating our mission. 
Table 1: list of plants tested and their traditional use

\begin{tabular}{|c|c|c|c|c|}
\hline Botanical name & $\begin{array}{l}\text { Collection } \\
\text { number }\end{array}$ & $\begin{array}{l}\text { Parts } \\
\text { tested }\end{array}$ & Plant family & Traditional uses \\
\hline Acridocarpus socotranus Olive & SPM01 & $\mathrm{L}$ & Malpighiaceae & Headaches $^{2}$ \\
\hline Boswellia socotranao Balf.fil & SPBs-03 & $\operatorname{Re}$ & Burseraceae & nervous disorders ${ }^{2}$ \\
\hline Boswellia elongata Balf. fil. & $\mathrm{SPe}-03$ & $\operatorname{Re}$ & Burseraceae & nervous disorders $^{2}$ \\
\hline Caralluma socotrana $\mathrm{N}$. Br & SPAs- 0.3 & Ap & Asclepediaceae & dyspepsia $^{2}$ \\
\hline Cephalocroton socotranus Balf.f & SPEu 05 & $\mathrm{~B}$ & Euphorbiaceae & to perfume the air ${ }^{1}$ \\
\hline Croton socotranus Balf. fil.. & SP-EU09 & B & Euphorbiaceae & healing wounds ${ }^{1}$ \\
\hline Dendrosicycos socotrana Balf.f. & $\mathrm{SP}-\mathrm{C} 03$ & $\mathrm{~B}, \mathrm{~L}$ & Cucurbitaceae & Problems of liver ${ }^{1}$ \\
\hline Dorstenia gigas Schweinf. ex Balf. fil. & SP Mo03 & $\mathrm{L}$ & Moraceae & Skin diseases $^{1}$ \\
\hline Eureiandra balfourii Cogn. \& Balf. fil. & $\mathrm{SP}-\mathrm{C} 05$ & $\mathrm{~T}$ & Cucurbitaceae & unknown \\
\hline Kalanchoe farinaceae Balf.f & $\mathrm{SP}-\mathrm{Cr} 08$ & $\mathrm{~L}$ & Crassulaceae & ulcers $^{1}$ \\
\hline Limonium sokotranum (Vierh) Radcl.Sm) & SP-P105 & $\mathrm{L}$ & Plumbaginaceae & Antifungal $^{2}$ \\
\hline Oldenlandia pulvinata & SP-Ru11 & Ap & Rubiaceae & Flavoring $^{2}$ \\
\hline Pulicaria diversifolia( Balf. $f$ & SP-Co12 & Ap & Compositae & Antispasmodic ${ }^{2}$ \\
\hline Pulicaria stephanocarpa( Balf. & $\mathrm{SP}-\mathrm{Co} 13$ & $\mathrm{~L}$ & Compositae & Headache $^{2}$ \\
\hline
\end{tabular}

L: leaves; F: fruits; T: tubers; Ap, aerial parts Re, resins B, bark, , R, roots.

${ }^{1}$ Most of the ethnomedical information has been taken from (Miller and Morris 2004), and from ${ }^{2}$ the local inhabitants

Table 2: Screening of endemic Soqotran plants for acetylcholinesterase inhibitory activity

\begin{tabular}{|c|c|c|c|c|c|}
\hline \multirow[b]{2}{*}{ Botanical name } & \multirow[b]{2}{*}{ Plant part tested } & \multirow[b]{2}{*}{ Extract yield ${ }^{\mathrm{a}}(\%)$} & \multirow[b]{2}{*}{ Extraction solvent } & \multicolumn{2}{|c|}{ AChE inhibition (\%) } \\
\hline & & & & $0.2 \mathrm{mg} / \mathrm{ml}$ & $0.05 \mathrm{mg} / \mathrm{ml}$ \\
\hline \multirow[t]{2}{*}{ Acridocarpus socotranus } & leaves & $((5.3)$ & $\mathrm{CHCl}_{3}$ & 23.68 & 2.13 \\
\hline & & $(15.5)$ & $\mathrm{MeOH}$ & 43.12 & 13.45 \\
\hline \multirow{2}{*}{ Boswellia socotranao } & Resin & $(51.2)$ & $\mathrm{CHCl}_{3}$ & 71.21 & 22.32 \\
\hline & & $(43.21)$ & $\mathrm{MeOH}$ & 35.23 & 0 \\
\hline \multirow[t]{2}{*}{ Boswellia elongatao } & Resin & $(47.2)$ & $\mathrm{CHCl}_{3}$ & 46.34 & 11.23 \\
\hline & & $(37.34)$ & $\mathrm{MeOH}$ & 17.87 & 0 \\
\hline \multirow[t]{2}{*}{ Caralluma socotrana } & Aerial parts & $(5.5)$ & $\mathrm{CHCl}_{3}$ & 45.34 & 15.29 \\
\hline & & (13.4) & $\mathrm{MeOH}$ & 15.3 & 0 \\
\hline \multirow{2}{*}{ Cephalocroton socotranus } & Bark & $(6.23)$ & $\mathrm{CHCl}_{3}$ & 51.1 & 14.35 \\
\hline & & $(1.03)$ & $\mathrm{MeOH}$ & 36.21 & 9.05 \\
\hline \multirow[t]{2}{*}{ Croton socotranus. } & Bark & $(1.81)$ & $\mathrm{CHCl}_{3}$ & 79.23 & 40.61 \\
\hline & & $(4.61)$ & $\mathrm{MeOH}$ & 13.23 & 0 \\
\hline \multirow[t]{2}{*}{ Dendrosicycos socotrana } & Bark & $(1.91)$ & $\mathrm{CHCl}_{3}$ & 23.35 & 3.21 \\
\hline & & $(5.72$ & $\mathrm{MeOH}$ & 31.95 & 5.4 \\
\hline \multirow{2}{*}{ Dendrosicycos socotrana } & leaves & (7.23.) & $\mathrm{CHCl}_{3}$ & 18.35 & 0 \\
\hline & & $(12.12$ & $\mathrm{MeOH}$ & 31.95 & 5.4 \\
\hline \multirow[t]{2}{*}{ Dorstenia gigas } & Leaves & $(2.54)$ & $\mathrm{CHCl}_{3}$ & 65.12 . & 18.51 \\
\hline & & $(6.35)$ & $\mathrm{MeOH}$ & 26.34 & 7.08 \\
\hline \multirow[t]{2}{*}{ Eureiandra balfourii } & Tuber & (1.04) & $\mathrm{CHCl}_{3}$ & 33.34 & 23.05 \\
\hline & & $(3.51)$ & $\mathrm{MeOH}$ & 58.61 & 19.42 \\
\hline \multirow{2}{*}{ Kalanchoe farinaceae } & Leaves & $(5.3)$ & $\mathrm{CHCl}_{3}$ & 45.21 & 17.02 \\
\hline & & (12.7) & $\mathrm{MeOH}$ & 32.23 & 10.56 \\
\hline \multirow[t]{2}{*}{ Limonium sokotranum } & Leaves & (4.61) & $\mathrm{CHCl}$ & 43.23 & 15.13 \\
\hline & & $(9.51)$ & $\mathrm{MeOH}$ & 29.2 & $12.45-$ \\
\hline \multirow[t]{2}{*}{ Oldenlandia pulvinata } & Aerial parts & $(3.91)$ & $\mathrm{CHCl}_{3}$ & 45.34 & 16.56 \\
\hline & & 9.21 & $\mathrm{MeOH}$ & 35.67 & 12.12 \\
\hline \multirow[t]{2}{*}{ Pulicaria diversifolia } & Aerial parts & $(3.61)$ & $\mathrm{CHCl}_{3}$ & 41.23 & 9.71 \\
\hline & & (11.31 & $\mathrm{MeOH}$ & 35.3 & 11.34 \\
\hline \multirow[t]{2}{*}{ Pulicaria stephanocarpa } & Leaves & $(2.30)$ & $\mathrm{CHCl}_{3}$ & 61.43 & 10.73 \\
\hline & & $(5.91)$ & $\mathrm{MeOH}$ & 23.21 & 5.51 \\
\hline Galanthamine $(8 \mu \mathrm{g} / \mathrm{ml})$ & & & & 87.8 & \\
\hline
\end{tabular}

${ }^{\text {a }}$ Percentage extract yield $(\mathrm{w} / \mathrm{w})$ was estimated as dry extract weight/dry starting material weight x 100 


\section{References}

1. Zarotsky, V., Sramek, J.J. and Culter, N.R. (2003) Galanthamine hydrobromide: an agent for Alzheimer's disease. Am. J., Health- System Pharmacist. 60: 446-452.

2. Howes, M.R, Perry, N S. L. and. Houghton P. J ( 2003) Plants with Traditional Uses and Activities, Relevant to the Management of Alzheimer's Disease and Other Cognitive Disorders Phytother. Res. 17, 1-18.

3. Schneider, L.S. (2001) Treatment of Alzheimer's disease with cholinesterase inhibitors. Clin.Geriatric Med, 17: $337-58$.

4. Houghton, P. J, Ren, Y. and Howes, M. J. (2006). Acetylcholinesterase inhibitors from plants and fungi. Nat. Prod. Rep., 23:181-199.

5. Miller, G.A and Morris, M. (2004) Ethnoflora of the Soqotra Archipelag. Charlesworth Group, Huddersfield, UK.

6. Ellman, G.L, Lourtney, D. K, Andres, V and Gmelin, G. (1961) A new and rapid colorimetric determination of acetylcholinesterase activity. Biochem. Pharmacol. . 7: 88-95.

7. Rhee, I.K, Van de Meent, M., Ingkaninan, K and Verpoorte R. (2001) Screening for acetylcholinesterase inhibitors from Amaryllidaceae using silica gel thin-layer chromatography in combination with bioactivity staining. J. Chromatography. A. 915: 217-223.

8. Ota, M and Houghton, P.J. (2005) Boswellic acid with acetylcholinesterase inhibitory properties from frankincense" $53^{\text {rd }}$ annual congress organized by society of medicinal plants, Societa Italiana di Fitochimica Florence, Italy $21^{\text {st }}-25^{\text {th }}$ (Book of abstracts, p. 339).

9. Franke, K, Porzel, A, Masaoud, M, Adam,G and Schmidt, J. (2001). Furanocoumarins from Dorstenia gigas. Phytochemistry, 56:611-21.

10. Miyazawa, M., Tsukamoto, T, Anzai, J and Ishikawa, Y. (2004) Insecticidal effect of phthalides and furanocoumarins from Angelica acutiloba against Drosophila melanogaster. J. Agric. and Food Chem. 52: 4401-5.

11. Kang, S.Y, Lee, K.Y, Sung, S.H, Park, M.J and Kim, Y.C.( 2001.) Coumarins isolated from Angelica gigas inhibit acetylcholinesterase: structure-activity relationships. J. Nat. Prod. 64:683-5.

12. Amaral, A. F. and Barnes,R. A. A.(1998) Tetrahydroprotoberberine alkaloid from Croton hemiargyreus Phytochemistry.. 47:1445-1447. 